\title{
INTRACTABLE CONFLICT IN SOUTHERN THAILAND
}

\author{
Enny Fathurachmi ${ }^{1}$
}

\begin{abstract}
Abstrak
Konflik di Thailand Selatan antara pemerintah Thailand dan kelompok muslim Pattani menjadi satu gambaran konflik berkepanjangan ketika tidak adanya pihak ketiga yang menjadi mediator dalam konflik ini. Jika dilihat dari durasinya, tuduhan satu dengan lainnya pada pihak yang berkonflik dan kematangan dari konflik itu sendiri maka, konflik Thailand Selatan sudah dapat dikategorikan sebagai intractability conflict. Kondisi konflik Thailand Selatan menjadi potret ketidakmaksimalan negosiasi yang dilakukan oleh kedua belah pihak berkonflik tanpa ada pihak ketiga yang menjadi mediator. Tulisan ini menawarkan strategi lain yang dapat dipergunakan dalam penyelesaian konflik dengan melibatkan pihak ketiga.
\end{abstract}

Kata-kata Kunci: Intractability Conflict, Thailand Selatan, resolusi konflik, pihak ketiga

\section{Introduction}

The conflict in southern Thailand between the government of Thailand and the Malay-Muslim community has yet to find a solution. Although there have been many attempts to resolve the conflict as of yet no progress has been made, even though the media reports both sides have agreed to end the conflict. The conflict has not received much international attention since the Thai government considers it part of their own domestic affairs. Nevertheless, evidence is mounting that the numbers of casualties from both sides in the conflict have been quite significant. During the sixty year conflict, there have been at least $3000 \mathrm{~s}$ victims (Thnaprarnsing: 2009).

In 2004 there was an escalation in the violence and the number of civilian casualties increased. The Taksin government was criticized by several countries for its handling of the matter. At the time, Indonesia offered to serve as a peace mediator for both parties, but the results of their negotiations did not end the dispute. Until now, no other third party has come forward to officially offer to mediate the conflict. This is what the Thai government wants since this will allow them to resolve this conflict in their own way.

The Thai government has created the image that the conflict in southern Thailand is

\footnotetext{
${ }^{1}$ Staf pengajar di Program Studi Hubungan Internasional, Universitas Mulawarman, Kalimantan Timur.
} 
no more than a separatist movement and that the violence is really just terrorism committed by Muslim communities who want to secede from the territory of Thailand. However, the root of the conflict itself is not widely known by the international community.

This main question of this paper is how should the process be started to settle the conflict in southern Thailand? In order to answer this question it examines to what extent the conflict has developed. This study limits its analysis of the conflict and examines the peace process from 2001 until 2008. This paper is divided into five sections which the first section is theoretical framework. The theoretical frameworks to analyze the conflict are intractability conflict and negotiation. The second section explains the conflict with ties on intractability characteristics. The third section examines efforts to solve the conflict. Here is will explain the government of Thailand policies that influenced by character of the regime. The fourth section is explaining alternative for settlement and the last is conclusion.

\section{Theoretical Framework}

\section{Intractability}

The conflict was identified as intractability conflict adhered with the characteristics such as; protracted time, identity denigration, conflict profitability, absence of ripeness, and solution polarization (Zartman:2005). Protraction is definitional characteristic of intractable conflict and it is self-reinforcing. The importance of protraction is not in its numerical duration but in that durations' effect (ibid). Duration sets up an increasing number of hurdles in the course of the conflict that add to the problems of treating (etymologically, "tracting") them (ibid). Conflicts are folded into the history and mythology of the parties, and ideological explanation for national efforts and problems, and so parties become reliant on them and are loath to part with them (Rosoux: 2000 in Zartman).

Identities in intractable conflicts not only are polarized but are actually dependent on the denigration of the other. The polarized conflict moves toward intractability when identities become zero sum and one identity actually depends on demeaning and demonizing the other: Being myself requires me to put you down and deny your full identity as human being (Zartman: 2005). Profitability is a commonplace-someone profits in any conflict-and so is an oft-forgotten characteristic of lasting conflict, as attention focuses much more the costs and losses, the pain and suffering that unresolved conflict brings to the losers.

Ripeness as a pressure toward negotiation tends to be absent in intractable conflict. Instead of a mutually hurting stalemate pushing the parties into a search for solutions, there is only a stable, soft, selfserving (4-S) stalemate that is preferable to any attainable solutions and the uncertainties of a search for them (Zartman: 1996 in Zartman: 
2005). Solutions in intractable conflicts also tend to be polarized. Solutions are related to the other characteristic of ripeness, a way out (Zartman: 2000 in Zartman: 2005). Whereas many conflicts are pulled toward one salient solution but experience difficulties in the process of getting there, intractable are generally characterized by the competing pulls of two salient solutions, posing an extreme Prisoners' Dilemma or collaboration problem, where noncooperation, though mutually hurtful, is the outcome logically preferred to unilateral attempts at cooperation (Hasenclever, Mayer, and Rittberger: 1997 in Zartman: 2002).

\section{Negotiation}

Definition of negotiation is a process by which states and other actors communicate and exchange proposals in an attempt to agree about the dimensions of conflict termination and their future relationship (Bercovitch and Jackson: 2001). In negotiation, there are three strategies for agreement namely: Contending, problem-solving, and yielding (Pruitt: 2002). In contending, negotiators pursue their goals by trying to persuade the other party to concede. This strategy is sometimes called competition (Thomas: 1976 in Pruitt: 2002)), distributive bargaining (Walton and McKersie: 1965 in Pruitt: 2002)), or claiming value. In problem solving, negotiators try to identify options that satisfy both parties' goals. This strategy is sometimes called collaboration, integrative bargaining, or creating value (ibid: 2002). In yielding, involves diminishing one's goals that is, reducing one's aspiration. This strategy is also sometimes called accommodation (ibid: 2002).

\section{Understanding the Conflict in Southern Thailand}

The conflict in southern Thailand is shaped by many complex factors. This conflict can be categorized as an insurgency according to the following characteristics. The first characteristic is the protraction or the duration of the conflict. This conflict first emerged in the 1940s and until now it has not been resolved. Because the conflict has gone on so long new additional issues have been added. Originally the complaint was against the minority cultural assimilation policy of the Thai government which emphasized the cultural principle of Buddhist singles in 1938 (Croissants: 2005). As it would develop later on, this conflict would be seen as a conflict of religion and culture.

The second characteristic has to do with identity. Since the beginning of the conflict, one of the complaints of the MalayMuslim community has to do with the preservation of their identity. This is influenced by historical factors since the southern region of Thailand was a sultanate and at one time belonged to the Kingdom of Siam. The province of Pattani, Yala, Narathiwat, and Satun once constituted " Patani Raya" or Greater Patani, wedged between the Siamese empire to its north and the Malacca Sultan to its south (Harish: 2006). Although it was the target of influence of both 
neighbors, their domains of authority diverged. Culturally, the people of Patani were aligned with Malacca but politically, they found themselves under Siamese suzerainty (ibid: 2006).

The third characteristic is profitability. The continued conflict in southern Thailand can be used as a justification for the government's support of the military's role in maintaining stability. The military is fairly dominant in Thailand and even the policies of the Prime Minister come mostly from the military (Moss: 2009).

The fourth characteristic is the ripeness of the conflict. The conflict in Thailand has been renewed became the Thai government is determined to resolve this issue their way (see figure 1). Although the conflict has lasted nearly sixty years, the government has no desire to invite a third party to mediate this conflict. Some parties such as the governments of Indonesia and Malaysia have only unofficially helped to facilitate a dialogue between both parties. Like the Thaksin government which is pre-occupied with preventing the internationalization of the conflict and has gone great lengths in attempting to convince the international community that the discord in southern Thailand is an internal problem (Harish: 2006)

The fifth characteristic is the solution. This conflict has now polarized the region. The Thai government still desires to maintain the southern region as part of Thailand, while the rebels want their own autonomy to be able to join with Malaysia which is the root of their culture.

\section{Efforts in the Peace Process to end the conflict}

In intractable conflict, there are three options for settlement namely; let the conflict settle itself, conflict management, and mediation and conflict resolution (Crocker, Hampson, and Aall: 2009). The conflict in southern Thailand tends to option two which conflict management by the government of Thailand. Typically, this involves freezing the conflict, through a negotiated and durable cease-fire and the subsequent, long-term deployment of outside forces (ibid).

Since this conflicted emerged, no third party has come forward to officially try to mediate the conflict. The process of conflict resolution has been monopolized by the government of Thailand and they continue to adopt a military approach to try to solve this matter. However, this approach has caused a recent escalation of conflict. In 2004, the administration of Taksin Sinawatra came down hard on the rebels. This resulted in 440 people being killed. This tragedy is known as the Tak Bai tragedy (Harish: 2006). It was this tragedy that triggered an international response condemning the incident, especially among Muslim majority countries. Taksin was preoccupied with the search for a security solution and used his manpower and resources accordingly. He seemed to believe that the effective use of military force in combination with the arrest and persecution of militant 
suspects would be able to bring this configuration under control (Jitpiromrsi and McCargo: 2008).

The changing tone of Thailand's new military-backed Prime Minister Surayud Chulanont and his emphasis on reconciliation raised hopes for ending the decade's long crisis in Thailand's Southernborder provinces of Patani, Yala, Narathiwat and Songkhla province. The violence in the South was used as one of the key justifications for the bloodless coup that ousted Thaksin Shinawatra in September 2006 (Horstmann: 2007).

In his first visit to the South, Surayud importantly apologized for the excesses of the previous government. Surayud promised to establish a constructive dialogue with all parties concerned and that he would use the recommendations of the National Reconciliation Commission (NRC) as his guideposts. Since the coup the new government has also made efforts to improve its ties with Malaysia and Indonesia. In November 2006, when Prime Minister Surayud visited Jakarta, he praised the peace process in Aceh as a model of Thailand should emulate. In 2006 Indonesia unofficially tried to facilitate dialogue between representatives of both warring parties to discuss the conflict in Bogor (Adnkronos: 2006). During this meeting, the new Thai government sent five negotiators. Their delegation was chaired by General Khwanchart Klahar, the supreme Commander of the southern Border Province Peace Building Command (SBPPC), who oversees the country's southern provinces. While the Muslims were represented by leaders of the Pattani Malay Consultative Congress (PMCC), an umbrella organization of insurgency groups in Southern Thailand. According to a spokesman for the Indonesian government, both sides have agreed that the settlement should be conducted peacefully through dialogue and should be in accordance with the Constitution of Thailand.

In these talks the two sides tried to adopt a problem-solving strategy. However, the dialogue quickly turned to a discussion of the lawsuit the Muslim party had filed to introduce Islamic law and their desire to make Pattani Malay (Yawi) the working language in the region, as well as other issues concerning the improvement of the local economy and education system. However, it was immediately apparently that neither party trusted each other so that these negotiations did not continue. The Thai government and some of the parties tried to reach a negotiation during the Langkawi Talk but these talks also failed.

The deadlock in negotiations between the Thailand government and rebels cannot be separated from the symmetry power in negotiating of both sides. The Thai government has a source of legitimacy and recognition from other countries including ASEAN which cannot intervene in this conflict because it concerns Thailand's internal affairs. The rebels also have a source of financial support from countries like Saudi Arabia, 
Qatar and Kuwait which support Islamic education in southern Thailand (Harish: 2006). Even organizations such as the Islamic development bank also provide scholarships for students to study Islam Pattani in the Middle East. It also postulated that fund were come from Libya and extended pro-Patani student organization in the Middle East which may have increased the means and the legitimacy of the armed conflict (Moss:2009). These outside influences have created a condition of symmetrical forces. This condition of symmetrical forces has complicated all attempts to achievement an agreement. New findings suggest that asymmetry is more propitious to achieving effective negotiations than near symmetry (Hornstein: 1965, Pruitt and Carnevale: 1993, Zartman and Rubin: 2000 in Zartman: 2002). 
Figure 1: Violent Resistance and Policies, 1959-2008

Source: Dana M. Moss available at

http://www.publications.villanova.edu/Concept/2009/Moss.pdf

\begin{tabular}{|c|c|c|}
\hline Phase & $\begin{array}{l}\text { Central Government Policy } \\
\text { on Southern Persistence }\end{array}$ & Movement Action \\
\hline 1959-69 & $\begin{array}{l}\text { Hard Policy: } \\
\text { Military campaign cultural } \\
\text { assimilation }\end{array}$ & $\begin{array}{l}\text { BNPP, BRN, PULO groups } \\
\text { formed for separatist state Guerilla } \\
\text { action initiated against military and } \\
\text { infrastructure }\end{array}$ \\
\hline $1970-75$ & $\begin{array}{l}\text { Hard Policy: } \\
\text { 7-years full-scale war }\end{array}$ & $\begin{array}{l}\text { Armed campaigns rises to highest } \\
\text { level since inception of groups }\end{array}$ \\
\hline $1975-79$ & $\begin{array}{l}\text { Hard Policy: } \\
\text { Cont.military presence }\end{array}$ & $\begin{array}{l}\text { Resources drained: seek } \\
\text { international support and fund; } \\
\text { Decreased violence but sustained } \\
\text { at lower; } \\
\text { Popular uprisings, police brutality } \\
\text { sustain separatist cause }\end{array}$ \\
\hline $1980-93$ & $\begin{array}{l}\text { Soft Policy: } \\
\text { Economic development, } \\
\text { Cultural diversity } \\
\text { Mediating structures } \\
\text { Amnesty }\end{array}$ & $\begin{array}{l}\text { Hundreds accept amnesty Malays } \\
\text { increase participation in allied } \\
\text { political parties } \\
\text { New Organization Bersatu formed } \\
\text { to coordinate activities BRN-C } \\
\text { agrees to peace accord with } \\
\text { military law level of violence, } \\
\text { sporadic }\end{array}$ \\
\hline $1994-96$ & $\begin{array}{l}\text { Hard Policy: } \\
\text { Peace accord } \\
\text { Declare void } \\
\text { Government "cracks down" }\end{array}$ & $\begin{array}{l}\text { Increased violence in direct } \\
\text { response to broken peace } \\
\text { agreement: groups take advantage } \\
\text { of Thai government instability }\end{array}$ \\
\hline $1997-00$ & $\begin{array}{l}\text { Hard and Soft Policy: } \\
\text { Amnesty offered } \\
\text { Con't punitiveness }\end{array}$ & $\begin{array}{l}\text { Few accept amnesty } \\
\text { Violent activity remains frequent }\end{array}$ \\
\hline $2001-06$ & $\begin{array}{l}\text { Hard Policy: } \\
\text { War on drugs } \\
\text { Denial of grievances } \\
\text { Mediating structures } \\
\text { Dismantled } \\
\text { Martial Law } \\
\text { Protestors killed } \\
\text { Economic development }\end{array}$ & $\begin{array}{l}\text { Violence increases against } \\
\text { increased } \\
\text { Military presence } \\
\text { Infrastructure and development } \\
\text { projects targeted } \\
\text { Any person seen as allied with the } \\
\text { Tai state is targeted }\end{array}$ \\
\hline $2006-08$ & $\begin{array}{l}\text { Hard Policy: } \\
\text { State of emergency } \\
\text { Martial law retained } \\
\text { SBPAC reopen }\end{array}$ & $\begin{array}{l}\text { Violence sustained: terrorist tactics } \\
\text { sustained }\end{array}$ \\
\hline
\end{tabular}




\section{Alternative settlement}

There have been some attempts to offer a solution to the conflict in southern Thailand as proposed by the NRC (National Reconciliation Commission). The National Reconciliation Commission (NRC), a body set up to propose policy alternatives in the South, recommended a range of measures designed to address issues of justice and identity as well as other socio-economic grievances. At the same time, the NRC tried to steer clear of directly addressing governance and decentralization issues (Jitpiromrsi and McCargo: 2008).

Since the events of the Tai Bak, many stakeholders demanded the government of Thailand resolving the conflict. Ideally, both parties invite a third party to mediate this conflict. I think that given the fairly long duration of conflict and the history of negotiations that always ended in deadlock then it is important that third parties are involved to help end the conflict. ASEAN is actually an ideal mediator, but if you compare this case with the case of Aceh in Indonesia it would perhaps be better if mediation is conducted by an outside party that is more neutral.

Many people think that with a population of less than 2 million people, compared with all the people of Thailand are as high as 60 million people, the injustice that is felt by the people of Pattani not international issues. For Southeast Asia, this issue should not be allowed to drag on because it can affect the stability of the region. Therefore, the media in Southeast Asia has a major interest for the issue of southern Thailand that aims to build peace. While at the national level, the mainstream of media and community in Thailand can work together to advocate for human rights violations and to influence government policy of Thailand. At the community level, to keep the dispute is not protracted into inter-community disputes; the community of media such as radio can contribute to building a peaceful dialogue between the people of Pattani and Thai. In this context, all types of media can be used strategically to build peace and good solution for South Thailand.

\section{Conclusion}

In conclusion is the Thai government tends to make conflict management as strategy. This conflict is deliberately maintained for the benefit of elites in this case the military. Some of the policies were put Thailand in "Martial law" situation. It enhances the role of the military as well as the budget to deal with conflicts on the border. However, this policy is not effective to curb the rebellion because the situation was even more resistant. This condition is even more draining the government. That why it is required an alternative to immediately resolve the conflict. The most appropriate option is to invite third parties to be involved as mediators. 


\section{References}

Adnkronosinternational. "Thailand: Govt and Muslims agree to end Southern conflict" available at http://www.adnkronos.com/AKI/English/Religion/?id=1.0.2503026716. 2006

Bercovitch, Jacob, and Jackson, Richard. "Negotiation or Mediation?: An Exploration of Factors Affecting the Choice of Conflict Management in International Conflict", Negotiation Journal, 2001. Vol:17, No:1, pp.59-77.

Croissant, Aurel. "Unrest in South Thailand: Contours, Causes, and Consequences since 2001" Contemporary Southeast Asia, Vol: 27, No: 1, pp.21-43. 2005

Crocker, Chester A, Hampson, Fen Oster, and Aall, Pamela. "Why Mediation Matters: Ending Intractable Conflicts" in Jacob Bercovitch, Victor Kremenyuk, and I. William Zartman (Eds), "The Sage Handbook of Conflict Resolution", London. 2009.

Harish, S.P. "Ethnic or Religious Cleavage? Investigating the Nature of the Conflict in Southern Thailand", Contemporary Southeast Asia, 2006. Vol: 28, No: 1, pp.48-69.

Horsmann, Alexander. "Approaching peace in Patani, Southern Thailand-some anthropological considerations" AEJ, 2008. Vol: 6, pp.57.

Jitpiromrsi, Srisompob and McCargo, Duncan. "A Ministry for the South: New Governance Proposals for Thailand's Southern Region", Contemporary Southeast Asia, 2008. Vol: 30, No: 3, pp.403-428.

Moss, Dana M. “Thailand's Unknown War: Malay-Muslim Separatism, Political Opportunities and the Dynamics of Violent Resistance" available at http:// www.publications.villanova.edu/Concept/2009/Moss.pdf. 2009

Pruitt, Dean G. "Strategy in Negotiation”, in A. Victor Kremenyuk (Eds), "International Negotiation: Analysis, Approaches, Issues" San Francisco. 2002.

"Solving the Conflict in Southern Thailand", USAWC Strategy Research Project. 2009.

Zartman, I. William, 2002, “The Structure of negotiation". in A. Victor Kremenyuk (Eds), "International Negotiation: Analysis, Approaches, Issues" San Francisco.

Zartman, I. William. "Analyzing Intractability", in Chester A Crocker, Fen Osler Hampson, and Pamela Aall (Eds), "Grasping the Nettle: Analyzing Cases of Intractable Conflict" Wahington DC. 2005. 


\section{Daftar Pustaka}

Bellah, Robert. 1957. Tokugawa Religion. New York: The Free Press.

Bolitho, Harold. 1974. Treasures Among Men: The Fudai Daimyo in Tokugawa Japan. New Haven: Yale University Press

Budiman, Kazuko. 2006. Sastra Agama Endo Shusaku: Dilema Memahami Tuhan. Depok: Universitas Indonesia.

- - - - - 2004. Imaji Tuhan dalam Novel Chimmoku Karya Endo Shusaku. Depok: Universitas Indonesia.

Chen Ka. 2007. Endo Shuusaku 'Chinmoku' no Kenkyuu-Nihon-teki Seishin Fuushi no Shouchou: Inoue Gomori ni tsuite - Nagasaki: Nagasaki University’s Academic

Endo, Shusaku. 1972. Chimmoku (Silence). Tokyo: The Kawata Press.

Gorai, Shigeru. 2002. Nihonjin to Gokuraku. Kyoto: Jinbunshoin.

Perry, Anderson. 1976. The Antinomies of Antonio Gramsci. London: New Left Review. 